\title{
"OMG can I have your meme lesson? TY": \\ Affective literacies and \\ collegial meaning-making in digitally-mediated participatory networks
}

\author{
Cherise McBride, Jabari Mahiri \\ Rebut: 05/12/2018 Acceptat: 21/12/2018
}

\begin{abstract}
Resumen
Como los recursos representativos y comunicativos cambian el panorama educativo, las diversas investigaciones realizadas indican la importancia de integrar las nuevas alfabetizaciones y herramientas de los medios en los repertorios de educadores. El presente estudio trazó las consecuencias semióticas de las redes participativas mediadas digitalmente para los educadores como diseñadores de experiencias de aprendizaje mientras trabajaron en desarrollar y demostrar método de instrucción mediado digitalmente. Utilizando métodos de etnografía digital, las fuentes de datos incluyeron publicaciones y respuestas de +300 blogs, composiciones digitales de trabajos multimodales en clase con profesores en entrenamiento, demostraciones de profesores expertos, registros de uso en línea y actividades de clase. Esta investigación identificó y describió las alfabetizaciones afectivas y las nuevas relaciones para la construcción de significado que surgieron cuando los educadores se involucraron en redes participativas mediadas digitalmente. El estudio amplía la comprensión de las funciones de los roles de la literacidad afectiva y la construcción de significados colegiados en el proceso de aprendizaje de el diseño de instrucción mediada digitalment.
\end{abstract}

Palabras clave: semiótica social, alfabetizaciones digitales, públicos en red, formación docente

\begin{abstract}
As representative and communicative resources change the educational landscape, research indicates the importance of teachers developing increasing competencies and confidence in the use of appropriate digital tools and texts for learning. The present study traced the semiotic consequences of digitally-mediated participatory networks for educators who were positioned as designers of learning experiences as they worked on developing and demonstrating digitally mediated instructional approaches. Using methods of digital ethnography, data sources included $300+$ blog posts and responses, multimodal digital compositions from in-class work by pre-service teachers, expert teacher demonstrations, online use logs, and fieldnotes on classroom activities. This research identified and described the affective literacies and new relationships for meaning-making that emerged as educators engaged in digital, participatory networks. The study extends understanding of the roles of affective literacies and collegial meaning-making in the process of learning to design digitally mediated instruction.
\end{abstract}

Keywords: Us Social Semiotics, Digital Literacies, Networked Publics, Teacher Education

\section{Digital Community}


MUSE Digital Pedagogy is a Google+ Community constructed by McBride, C. (2018) to mediate the learning and pedagogical design activities of pre-service teachers in a graduate class entitled "Integrating Technology into Secondary English Instruction." Mahiri, J. (2011) is the faculty director of the Multicultural Urban Secondary English (MUSE) master's degree and and teacher credential program of which this class was a part. This article focuses on members of the 2017 and 2018 MUSE cohorts who were participants in the class as well as other educators who joined this wider Google+ Community. The key question for this research was: what are the affective literacies and new relationships for meaningmaking that emerge as educators engage in digitally-mediated participatory networks?

One of the numerous examples of "affective literacies" and the new relationships we are calling "collegial meaning-making" that took place in this digitally-mediated participatory network is seen in the blog post below to which Violaa, a practicing teacher who was in an earlier version of the "Integrating Technology" class, responded, "OMG [Oh my God], can I have your meme lesson? TY [Thank you]." Marina, the class participant who posted the blog, responded, "Yeah! Of course Viola. I'll share it with you! It was one of the most successful and fun lessons I have ever taught."

In her blog post, Marina described her design of a learning experience for students in her high school English class as follows:

This week, I did a vocabulary lesson about literary devices using the Frayer model ${ }^{b}$ to introduce the concepts. After the vocab lesson, students used their notes to analyze memes for literary devices and provide evidence for their claim. The lesson was very successful, students maintain focus and high levels of energy throughout the process and students who don't usually volunteer to participate were doing so throughout the lesson. I realized how useful memes and images are in learning.

I am reconsidering my plan and am considering either having students create cover pages for a selected number of short stories in "... And the Earth did not Devour Him"; by Tomás Rivera that asks them to symbolically represent the literary devices and themes in the chapter or having them be responsible for creating memes for upcoming vocabulary words to demonstrate knowledge of application. I am excited about incorporating the creation of images to demonstrate knowledge of literary terms. I will be meeting with my CT [Cooperating Teacher] to discuss my upcoming unit this Tuesday and will decide how to proceed with this project from there (blog post, 4/15/2018).

Literary devices like personification, foreshadowing, and satire are elements used by writers to give greater depth and meaning to a story. Fuller comprehension of meanings and deeper personal experiences of a text are dependent on students' abilities to recognize when and how these devices are being employed. The word "meme" comes from "memetic," the term for a controversial concept that ideas can be viewed as "living" organisms that can reproduce and spread through what might be called an "ideosphere." Marina's use of memes as humorous images, or animations, or brief phrases, etc. that are rapidly shared among Internet users to link to various literary devices operating in a text allowed her students to utilize ideas they are already familiar with as Internet users to better understand how other meanings are spread throughout and complicated within a literary text.

The kinds of affective literacies and collegial meaning-making activities being shared by Marina and Viola took place in the context of them developing their digital pedagogical approaches and skills as "Designers of Learning Experiences" (DLE). McBride, C. (2018) (Under Review) defined DLE as a "tinkerer" teacher identity with regard to incorporating digital texts and tools into instruction that is student-

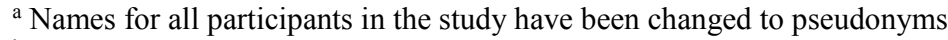

$\mathrm{b}$ The Frayer model is a graphic organizer designed to help students with vocabulary concept development. It features five subsections including a space for the concept or work, definition, characteristics, examples, and non-examples. It was originally developed by Dorothy Frayer (1969).
} 
centered first and foremost rather than teacher-centered. At the core of this identity is an ability to take Available Designs, (New London Group, 2000) of lesson plans, tutorials, new media genres, and attend to their respective grammars to arrange new designs for use in learning experiences for students. Taking an agentive role is at the center of this process.

Drawing from multiliteracies pedagogy, the language of design is concerned with transforming resources into historically and culturally received patterns of meaning (New London Group, 2000). The enactment of designing enables people to "reconstruct and renegotiate their identities," (p. 23) as learners in semiotic processes of making-meaning. Furthermore, DLEs, while developing technological fluency, are not just technology users. They develop technological pedagogical knowledge to consider implications for digitally mediated teaching and learning.

So, DLE's are not just technology teachers. They demonstrate evidence of a robust rationale of technology use that connects the functions of the technology (Koehler \& Mishra, 2006). When DLEs engage as connected learners and try on new media technologies and their affordances, they also gain much-needed, nuanced perspectives about the experiences of youth as learners. Earlier evidence for this was provided in a year-long study that Mahiri, J. (2011) conducted to facilitate the entire faculty of a Northern California, urban high school in developing the confidence and competencies to select and use appropriate digital texts and tools to improve student learning (2011). A key finding was the importance of supportive and collegial relationships among the faculty that enhanced their overall learning in conjunction with the effectiveness of a professional development approach of "teachers teaching teachers."

In addition to Marina and Viola, this article looks at the work of other members of the 2017 and 2018 class cohorts as well as the demonstrations to these classes by expert teachers enacting roles of Designers of Learning Experiences in which their own meaning-making processes regarding instruction are expanded through affective literacies and collegial meaning-making.

\section{Digital Integration, Affective Literacies, and Collegial Meaning-Making}

\subsection{Digital Integration}

Effectively training pre-service teachers to integrate digital technology within their practice has required teacher education programs to increase focus on how teacher educators' technological expertise can be made visible in university courses (Borthwick et al., 2004; Dexter, Doring \& Riedel, 2006; Gomez, Sherin, Griesdorn \& Finn, 2008; Brush \& Saye, 2009). As Dexter and colleagues found in their five-year study of a college-wide teacher education technology integration study, technology into their teaching greatly depended on their own prior knowledge and experience with technology (Dexter, Doring \& Riedel, 2006). It was found that when teacher education programs included a focus on technology integration, there often were few opportunities for pre-service teachers to engage in what Ertmer (2005) calls vicarious exploration - opportunities to observe practitioners actually model technology integration. Vicarious exploration also provided pre-service teachers opportunities for reflection on their beliefs about the uses of technology in instruction.

Additionally, for pre-service teachers to integrate technology within a content-specific frame they must exercise Technological Content Knowledge (TCK), defined as "an understanding of the manner in which technology and content influence and constrain one another," (Mishra \& Koehler, 2009, p. 63). Due to the ever-changing nature of technology, teachers must also become early adopters of new technology (Straub, 2009) and engage in continued professional development to not only increase their technological knowledge but also their Pedagogical Content Knowledge (Brzycki, \& Dudt, 2005). 
Pedagogical Content Knowledge demands both a facility with technology tools and an understanding of how particular tools afford deeper content understandings (Darling-Hammond, 2006; Kleiner, Thomas, \& Lewis, 2007). Thus, technology tools cannot simply be added to literacy instruction; rather, technology must be integrated in ways such that it transforms the learning experience while being responsive to the diverse contexts of schools and student populations (National Council of Teachers of English, 2013; Mahiri, 2011; Hicks \& Turner, 2013). Importantly, because literacy development is deeply situated within sociocultural contexts, pre-service teachers must also implement instruction that is critical of how knowledge is constructed through the use of technological tools (Morrell, 2005).

\subsection{Affective Literacies}

Teachers in the connected learning environment were engaged in communities of practice (Lave \& Wenger, 1991) focused on developing literacy pedagogy and content through immersion in digital technologies. This study defines meaning-making consistent with the approach of new literacies. Lankshear and Knobel's (2007) characterization of new literacies as those which are comprised of both new "ethos stuff" and new "technical stuff," offers a useful framework for imagining the literacy practices of participants in this study. New "ethos stuff" is more participatory, collaborative, and distributed than conventional literacies.

Affect involves emotional, political and networked dimensions and is studied within a variety of fields including cultural studies, literacy, and technological studies. Hickey-Moody \& Haworth define affect as "the notion of taking something on, of changing in relation to an experience or an encounter," (2009, p. 79). Affect is also defined as an agentive intensity that traverses the self and society (Massumi, 2002; Seigworth \& Gregg, 2010). Affect has been described as non-narrativized emotion and calls upon the "not yet" nature of emotion (Spinoza, in Seigworth \& Gregg, 2010) or the sense of moment-to-moment unfolding of activity. Papacharissi employs affect to understand pre-emotive intensity and processes of pre-mediation or anticipation of events prior to their occurrence to understand affective publics in networked activity (2015). Her study of the Arab Spring uprising and other social movements explored the discursive streams that came into being through networked activity on the social media platform Twitter.

Some current studies of digital literacies draw attention to affective dimensions of literacy - those that extend beyond strictly cognitive processes to include aspects such as emotional, sensorial, and an embodied nature of literacies (Mills, Stornaiuolo, Smith, \& Pandya, 2017). Within the affective domain of literacy, "emergence" particularly zeroes in on the transient, mobile dimension of literacy practices (Stornaiuolo, Smith, \& Phillips, 2017). Through this analytical lens, meaning can be perceived as a dynamic that "bubbles up" (p.77) among users through sociomaterial assemblages of interactions with technologies, broadly defined. While affect can be fleeting and ephemeral, new "technical stuff" such as networked publics afford "persistence"(boyd, 2007) wherein digital material can be captured and retrieved for posterity. Our study showed how this capability of digital devices to capture, retrieve, and amplify sharing and dissemination of ideas is key to ways affective literacies are reflected in our Google+ Community as well as ways collegial meaning-making is manifested.

\subsection{Collegial Meaning-Making}

Focal participants in the connected learning environment were engaged in a community of practice (Lave \& Wenger, 1991) focused on facilitating their teaching of technology and literacy. Their positionality as colleagues in the graduate education program was centered around constructing identities as teachers who would apply their acquired knowledge to practice in their own secondary school classrooms. This study draws from the idea of collegiality and collegial meaning-making as foundational to building professional community. Mawhinney (2010) discusses collegiality as coping, humor, social support, and knowledge-sharing in unstructured, informal, congregational spaces such as teacher lounges. Collegial educator relationships have been shown to have an important role in lower 
teacher attrition, positive school climate, and higher student outcomes in schools (Berry, Daughtrey, \& Wieder, 2009; Mawhinney, 2008; Goddard, Goddard, \& Tschannen-Moran, 2007). Recognizing that all learning is relational (McDermott, 1977), this study incorporated a view of collegiality that centers the relationships for meaning-making among teachers as they developed their teacher identities, while simultaneously developing literacy pedagogy and content through immersion in digital technologies.

Participatory networks afford a particular kind of meaning-making as semiotic processes are mutually engaged and exchanged across social networking sites or other Web 2.0 platforms. Research on teacher learning in networked spaces-those mediated by digitally-networked technologies (boyd, 2007), has highlighted the collegial affordances of such environments (Baker-Doyle, 2016). Networked spaces are just one example of a Personal Learning Network or PLN (Tobin, 1998), which may be digitally-mediated or not, and which may be integrated into a larger web of social network ties. Research has found that digitally-mediated PLNs support teachers' affective, social, cognitive, and identity development through their participatory features (Trust, Krutka, \& Carpenter, 2016), with $96 \%$ of respondents $(n=487)$ describing changes to their teaching and learning environments among many self-reported benefits. Other research reports that PLNs increase peer support (Davis, 2015; Kelly \& Antonio, 2016).

Jarzabkowski (2002) defines collegiality as teachers' involvement with their peers on any levelintellectual, moral, political, social and/or emotional (p. 2). This definition distinguishes collegiality from collaboration which is sometimes employed to refer only to that which is instrumental to the profession. Similarly, social network theory recognizes that individuals' web of connections makes it so that professional connections are but one resource of many. As such, PLNs are but one in a web of multiple networks of which teachers are a part.

Jarzabkowski, in highlighting the role of congeniality (2002), along with others (Fine, 1988; Ashforth \& Humphrey, 1995), demonstrates that social sharing among teachers can lead to improved cooperation, communication, and emotional commitment. Following a systematic review of 20 years of research on teacher PLNs, Lantz-Anderson, Lundin \& Selwyn (2018) highlighted that while there is evidence of the emotional and affective characteristics of these spaces, a gap remains in the empirical literature on how the affective consequences are taking place. The present study addresses this gap in understanding affective consequences in conjunction with exploring how collegial meaning-making occurred in this digital learning community.

\section{Digital Ethnography}

Digital ethnography has many forms, is used within a wide range of disciplines, and is referred to by a variety of terms. Varis (2014), for example, noted some of the different labels including "virtual ethnography," "cyberethnography," "discourse-centered online ethnography," "Internet-related ethnography," and "netnography" to name a few. Although these terms can signal different understandings of what ethnography is, they all revolve around the collection and analysis of digitally mediated communication. Like Varis, rather than being limited to specific techniques or methods of collecting and analyzing data, we see digital ethnography mainly as "an approach" to studying digitally mediated communication and culture. With this approach, we intentionally utilized multiple and multimodal texts and tools for capturing and analyzing meanings and meaning-making along with individual and collective communicative practices that reflected collegiality with the understanding that all these things are intricately linked to or determined by the nature of the digital devices being used. Data sources generated around expert teachers' digital pedagogy demonstrations to the Integrating Technology classes included more than 300 blog posts and responses, multimodal digital compositions from in-class work, online use logs, researchers' observations and descriptive notes on class activities, and reflective notes on informal discussions with the participants. 


\subsection{Site}

The Multicultural Urban Secondary English (MUSE) program at the University of California Berkeley has continually evolved courses to facilitate its pre-service teachers increasing their confidence and competence in using digital texts and tools to mediate student learning. These continual changes have been toward increasing focus on the knowledge, skills, and experiences necessary to design transformative technology-integrated lessons (Schmidt, et al, 2009, National Council of Teachers of English, 2013).

The physical site of this study was a technology lab equipped with large-screen, Internet-connected, desktop computers at 18 workstations, all lined in rows facing a big projector-screen at the front of the classroom. Additional sites were the Google+ Community platform and the myriad virtual spaces, digital apps and programs, and other digital resources accessible via the Internet.

\subsection{Participants}

Focal participants were 13 pre-service teachers who in 2017 were in their first year of a two-year MUSE program and 13 additional pre-service teachers who were in the 2018 version of the class. The program leads to a masters' degree and teaching credential for middle and high school English. During this first year of the program, all pre-service teachers were involved in classroom observations and student teaching, so they had direct instructional connections with students in schools. Participants from both classes were linked through the Google+ Community. Additional participants were practicing teachers as well as expert teachers who supported the Integrating Technology course by giving in-class demonstration on ways they had utilized digital tools in their instruction. All the digital tool demonstrations were web-based so that focal participants and others could access them in their own practice without having to purchase or install software. The tools were also accessible from netbooks as these are a common in secondary classrooms.

\subsection{Data Collection}

The researchers collected in-class work, written responses, blog posts, final project lesson plans, and social media posts of the focal participants, and these were all conserved in the Google+ Community. The focal participants also were asked to tag all artifacts they created to facilitate tracking content they generated in conjunction with the course. The demonstrations by expert teachers were a key driver for the focal participants' generation of digital content, and data was collected on each of three demonstrations in three stages. Prior to each demonstration, the expert teachers uploaded their lesson plans and materials to the course's Google Drive folder to be shared with the focal participants. During the demonstrations, the researchers video-recorded classroom interactions and took descriptive field notes. Finally, at the conclusion of each demonstration, the focal participants were asked to compose written responses to gauge their understanding of the tool presented in the demonstration and to selfassess their potential to integrate both the lesson design and technology tool into their practice. Reflective fieldnotes were taken after individual conversations with the researchers and on general class discussions after the class periods ended.

\subsection{Data Analysis}

The data sources were read or viewed several times with a focus on instances of affective literacies and/or collegial meaning-making as they were revealed in the focal participants' processes of designing digitally mediated learning experiences for current or future students. Since their processes for designing learning that was digitally mediated were linked to the demonstrations by the expert teachers, the talk, activities, interaction with materials, work submitted, and media posts were analyzed for evidence of uptake as well as collegiality on the part of the focal participants in the class. These sources of data were then formally coded for instances of affect associated with developing digital literacies as well as for instances of collegial meaning-making. In doing so, we saw that these instances were primarily reflected in three ways. First, they occurred within and between the cohort of focal teachers from both classes. 
They also occurred between the focal teachers in the classes and the experienced teachers who were members of the Google+ Community. Finally, they occurred between focal and focal teachers in two classes and the students they were teaching.

\section{Findings}

Findings are presented in the three categories that the analysis of data revealed beginning with the focal teachers in the two classes, moving to interactions between focal teachers and practicing teachers, and concluding with interactions between focal teachers and their students. It became clear that there were frequent overlaps between instances of affective literacies and instances of collegial meaning-making, so discussion in each of the three categories illuminates how these two features intersected in and across data sources.

\subsection{Affective Literacies \& Collegial Meaning-Making Among Focal Teachers}

Even in its brevity, the two-line exchange between Marina and Viola in the opening vignette of this article revealed a lot about their meaning-making processes. An emergent moment-by-moment recapitulation of their exchange captured in a reflective fieldnote by McBride, C. (2018) highlights the affective literacies in Marina and Viola's engagement:

Viola, a first-year classroom teacher [who participated in the 2017 class] is browsing the MUSE Digital Pedagogy blog for ideas when she comes across a recent post from Marina, a preservice teacher, about her English classroom. She gasps in surprise and immediately clicks the +1 under Marina's post to share her excitement. Viola then clicks the comment box underneath Marina's post and types a quick oneliner to Marina: "OMG can I have your meme lesson TY". Marina receives the notification of Viola's activity on her post a short time later and returns to the site. Smiling, she clicks in the box beneath Viola's picture and comment to type a response: "Yeah! Of course Viola. I'll share it with you! It was one of the most successful and fun lessons I have ever taught." She feels positive emotion recalling the success of her lesson and with the thought of sharing it with a colleague (McBride, C. (2018), fieldnote, 4/15/2018).

This accentuated account of the activity by McBride, C. (2018) is consistent with what Leander and Boldt call a strategic sketch-an "opportunity to think and feel within the possibilities of the data" (2012, p. 27), in this case based on data from the time-stamped blog posts and responses. Further evidence of affect is offered in the analysis of the participants' discourse below.

Viola's inquiry to Marina begins with an emphatic OMG-a signifier used to indicate surprise. Her construction of the lexical assemblage: "OMG can I have your meme lesson TY" in a register most commonly used in texting-without punctuation, or any formalities such as a named addressing of Marina demonstrates a level of ease and familiarity with Marina. Juxtaposed with the formatting of the rest of the comment, the capitalization of TY emphasizes the abbreviation "thank you," demonstrating affect and collegiality simultaneously in terms of expressed gratitude for the sharing of knowledge. These interactions index the existence of a relationship that affords collegial meaning-making: up to and including the tacit norms and expectations within the Google+ Community that allowed these two colleagues to "share" freely-both in word and deed. Not only were they each able to post these messages to one another such that all other members in the community would see them, but also they committed to the sharing of resources.

Marina's use of exclamation points conveys a degree of excitement in being willing to share resources with Viola in an act of collegiality: "Yeah! Of course Viola. I'll share it with you!" These activities are characteristic of the energizing potential of emergence. The digital platform affords a kind of spontaneous exchange through its comments feature. The comments and +1 response features permit a degree of organic flow of emotion by allowing participants multiple points through which to express 
their engagement with one another. While there are a range of examples that can be drawn from our data, we will present two additional vignettes as exemplars to demonstrate the kinds of collegial meaning-making and affective literacies that were found in this study.

As a blog post dated 4/16/2017, Nett shared an outline of her final learning design that was required for the 2017 class. It was a "digital quilt" project based on Toni Morrison's novel Beloved designed for a 12th grade English class. The objective was for students to work with the digital composing tool Padlet to collaboratively create a "quilt" that would represent their assigned character for the novel. Each of the squares for the quilt would need to integrate a symbol along with a quote from the novel $\&$ a written explanation of how the quote related to or exemplified their selected symbol. Nett included needed technology tools, and both content area standards and technological standards to outline the expectations as well as evaluation criteria for the project. The only technology tools listed for the project were Padlet and Google (for sourcing symbols). She specified that students would be evaluated on how well they collaborated in their teams to use time and how they distributed knowledge effectively to craft the digital artifact.

April, another focal teacher in the 2017 class responded to Nett's blog post with the following comment: This is a super great lesson that definitely links to your previous work with symbols with Lord of the Flies. I love the idea of the quilt manifesting as a digital construct. I personally am obsessed with quilts in fiction, and I think the quilt is an important framework to understand Beloved as well. One question I have is: will students work on any kind of graphic design or image creation beyond padlet, like through canva or photoshop? Also, will this symbol be used by your students in any other contexts or projects? (Blog post, 4/17/2017)

April's response demonstrates affective literacies in the way she shares her own "obsession" with the existence of quilts in fiction and her appreciation of its manifestation as a digital construct. Her use of these terms create a personal, embodied connection with Nett's idea before moving on to an affirmation of Nett's choice of using it to analyze this particular text. April's post also reflects collegiality in its suggestion for Nett to consider allowing an opportunity for her students to create the visual images of their own rather than only collecting ones from the Internet. She suggests photo editing tools including Canva, which has been previously demonstrated in the class (field notes, 3/8/2017). Nett replies a short time after April's reply:

I really like the idea of having students craft their own images in canva or photoshop. I think [I] might add those in as an extension opportunity for students that really want to challenge themselves! I also like the idea of revisiting the quilts within other units. Thanks for your feed back (blog post, 4/17/2017).

Nett uses an exclamation point to emphasize her enthusiasm. Weeks later, as revealed in the studentfacing instructional slides Nett submitted as part of her final project, Nett indeed integrated the feedback from April and offered the option for students to create their own images as an extension activity:

[SLIDES 11 \& 12] Two tutorials are posted on Google Classrooms: one for Padlet and one for Pixlr. Padlet is the platform on which you will be completing your digital quilts and it has a mobile app that is free to download. Pixlr provides you a platform on which you can craft your own, customized images if you want to challenge yourself. (Lesson Plan, 5/11/2017)

This uptake demonstrates collegiality that had an impact on Nett' practice. Not only did April's input affect Nett's affective experience in the Google+ Community, it also turned into a way for Nett to create an extended learning opportunity for her students. In this way, Nett and April engaged in collegial meaning-making to make Nett's lesson to more thoroughly reflect the meanings they had come to regard as most consequential. 


\subsection{Affective Literacies \& Collegial Meaning-Making Beyond Focal Teachers}

In a week when the Google + blog prompt title was "Free Write," Celina, a pre-service teacher in the 2017 class, who is generally soft spoken in the tech course, took time to compose a blog post laden with strong emotion. It is presented in its entirety to capture the narrative arc and context:

After listening to the news lately, I've felt a deep sense of indignation for victims of hate crimes. I just want to reach through the screen and upend those responsible for hurting others out of purely mal intent. The world seems to have become increasingly desensitized in our digital age-I can only understand how our students feel incensed or upset by what they hear in the news, through their various social media outlets. They may also feel helpless and confused about their reactions, especially if the upsetting events take place halfway across the globe. I wonder how as educators, we can address these moments and provide a digital space where students may voice their concerns and calls for change.

Youth Radio and Youth Voices provide the perfect platform for students to express a full-bodied product of their opinions and attitudes. Not limited to just words on a page, students may incorporate their own strong individual or collaborative voices and pair their pieces with a variety of mediums like music, images, and clips from important historical moments. I think it's important for students, in their heated moments, to channel their frustrations into digital mediums, because their voices can be published digitally, and heard by virtually anyone with the ear to listen. In this age of globalization and limitless access to information, we must always support our students and allow them the space and time to voice their thoughts on a public platform and develop as active participants for positive social change. (blog post, 3/12/2017)

Celina openly reflected her "deep sense" of indignation." She has a visceral reaction to the hate crimes she has seen in recent news-one that leads her to not only imagine a kind of retributive physical intervention, but ultimately leads her to question how she will intervene pedagogically to allow her students a space to express themselves. As we zero in on this moment-to-moment embodied experience of meaning-making we see that Celina's "wondering" about the world emerges from her shared empathy with students' helplessness and confusion that stands in sharp contrast with an apparent "desensitization" that she feels correlates with the digital age in which we live and particularly through what students experience in their social media feeds. In an ironic connection to the observation she makes about her students, she too is using a social media outlet, although to express indignation at what is happening in the world. Yet in this instance her response is met with the the of a collegial network of support.

Kyle is not a focal teacher in either of the classes, but instead is an experienced high school history teacher who participated in the Google+ Community. He uses blended learning in his classroom in the northeastern United States. Kyle clicked a +1 in response to Celina's post and chimed in by posting a comment in reply to her post. His comment affirmed Celina's sentiment, offering her collegial support to make meaning of the emotions she experiences about her students' concerns. Kyle further linked the desires they appear to share to their professional goals as literacy instructors:

It's important that students get the support they need to effectively convey their concerns and calls for change. Providing students with the opportunities you describe here accounts for so many literacy standards. Most importantly, it supports developing capacity for substantive and sound arguments. (blog post, 3/12/2017)

Kyle demonstrated collegiality in validating the feelings of Celina's students that she has shared, and by proxy, Celina's as well. Kyle also affirmed the pedagogical responses Celina has offered as ones that have "potential for establishing norms that our kids need to be successful in the digital age," (blog post $3 / 12 / 2017$ ) just further down in the same post. Kyle's use of the phrase "our kids" gestures toward a 
collective solidarity that even though the students in question are over three thousand miles apart, there is a sense of shared responsibility, shared identity, and collective work in the teaching that each of them are doing. As a more experienced teacher, his inclusion of the literacy standards also reinforces Celina's burgeoning sense of aligning student activities with academic goals as a pre-service teacher who is still learning to work with content standards. Finally, at the end of the exchange, Kyle shared his own ideas for digital citizenship that he uses with his students:

I remind my students that everything they publish (including email) needs to be appropriate if read in court as well as the thanksgiving table (blog post, 3/12/2017).

Together through their imagining, Celina and Kyle unfolded a future of what might relieve or support what they have agreed is a worthwhile personal and pedagogical challenge. Their affective literacies led to a sharing of visions of how they might respond to the pressing needs of their students in tumultuous times, through the use of digital media in ways that resonant with their own experiences and that have validated and affirmed their own relationship as colleagues.

While Celina and Kyle forged a connection within the Google+ Community, the next blog post demonstrates how focal teachers were guided to explore participatory networks like Twitter. It offers beginning insight into how Ashley, another focal teacher in the 2017 class used a classroom assignment to engage in meaning-making relationships that represented affective literacies and collegiality with educators not only beyond the context of the two classes but also beyond the Google+ Community.

This \#ohedchat was my real engagement with a live Twitter \#edchat and I really enjoyed it! I often read, retweet, and like the posts during the weekly \#hiphoped chat, but I haven't had the courage to engage in the conversation. Now I feel ready to engage! I am interested in possibly involving \#connectedED in my classroom next year. I think it would be valuable to hear student voices when educators are asking important questions like how to engage students and make the content relevant. I joined the Northern CA and Southern CA Google For Educators Google+ pages and have been able to see the interactions between different educators. (blog post, 2/25/2017)

Ashley's mention of \#ohedchat refers to 30 minute in-class assignment wherein the preservice teachers engaged in a synchronous exploration of Twitter chat for educators. While officially called Ohio Educators Chat, the chat draws educators from all over the country and is one of similar chats virtually "hosted" by states all over the United States. The assignment reflected their first in a series of "ConnectED" experiences, an ode to the \#connectED hashtag used on Twitter to index the online interactions of educators who identify as digitally-connected educators. During the chat whose theme for that instantiation "Nutritional Literacy," the focal teachers logged in from their professional accounts and practiced the ins and outs of using the appropriate question and answer protocols and which view to select: "top" or "latest" (field note, 2/22/2017).

The room was abuzz with excitement as students typed loudly, gasped, searched their computer screens with wide eyes for clues on how to navigate the fast-moving chat. Several of the focal teachers expressed sensorial, embodied experiences associated with the Twitter chat. For example, April shared "it honestly surprised me that so many people were on Twitter, passionately discussing pedagogy at $5 \mathrm{pm}$ on a Wednesday" (written reflection, 4/29/2017) or Carrie's reflection: "I found these experiences disorienting and exciting simultaneously" (written reflection, 4/30/2017). Each of these demonstrates an affective response to the literacy practice of collective synchronous microblogging on Twitter.

In the blog post above, Ashley articulates affective literacies in the emergent feelings of her description of a newfound "courage" that enables her to now feel "ready" to engage not only as a participant but even involving it in her classroom as a pedagogical strategy. The sense of "live" Twitter chat appears to 
invigorate her to not only consider using the social media platform in her classroom but she also joined other participatory network spaces in order to "see the interactions between different educators."

The way that Ashley's meaning-making launched into a spring board of collegial activity that extended beyond the synchronous chat exemplifies a collegial meaning-making beyond focal teachers experienced by a number of the study participants. Ashley ultimately continued her engagement with Twitter such that her final project for the course was a Twitter-based debate in tandem with George Orwell's Animal Farm. In this way, the collegiality she found invigorating appears to have intersected with her pedagogical decision making over the course of the class

\subsection{Affective Literacies \& Collegiality with Students}

Darla is a focal participant in the 2017 class who also taught English Language Development in a high school context. Like several of the focal teachers, throughout the digital pedagogy course Darla made it clear that she was determined to try out the pedagogical tools and strategies shared in the course for the sake of her students' learning, particularly for their development of digital literacies. Partway through the course, she posted the following in the Google+ Community:

I have been thinking a lot about what I mentioned in class, about my students not knowing how to use computers at all. I am thinking of talking to my cooperating teacher and ask for her help to create a small unit and at least teach them how to use one of the tools that we have been tinkering in class with. I believe that this will help my students a lot in their future classes (blog post, 3/12/2017).

Darla's collegiality with her students is evident in the post in that she advocates for the expansion of the exposure to and experience with technological tools, thereby engaging their intellectual needs. Later she builds upon this collegial stance with her students even as she works on her own final project for the course in the professional community of learners. Her final project for the course is a series lessons that calls for her students to describe a school policy based on readings and compare it to one from their home countries. They are to create multimodal compositions using Padlet, featuring audiorecordings of their own voices, images from the web, quotes from nonfiction text, and text definitions. As part of her preparation for teaching, Darla creates a sample digital artifact and shares it with her students as a model text they can use for scaffolding their practice. Although she has been sharing the meaning-making process all along, once she has taught the lesson, she shares her final artifact to the Google+ Community with her teacher colleagues, as well as links to two finished projects completed by her students with the comment about her students: "they loved using Padlet," (Blog post, 5/3/2017).

By allowing her students to be present in the Google+ Community through not only their creations including their voices, but their reflections throughout the process, Darla demonstrates collegial meaning-making with her students. She has invited her students into not only the Google+ Community, but the space of collegial meaning-making, by allowing their needs, interests, and social connections to guide and adapt her pedagogical decision making. These moves toward collegial meaning-making show up both in the format for their lesson as well as the content of what went forward. By using a technology tool with multimodal composing capacity including audio recording, Darla demonstrates a responsiveness to their intellectual needs as emergent bilingual students. Similarly, structuring the content around material that had proven culturally relevant and engaging for her students' social and emotional needs, Darla carries out meaning-making that builds upon and furthers collegial relationships with her students.

The findings highlighted in this study demonstrate a range of literacies that occurred in networked spaces in terms of affective literacies and collegial meaning-making. Focal teachers employed affective literacies and collegiality in their interactions with colleagues in their immediate contexts of their respective 2017 and 2018 classes, beyond the classes in the Google+ Community, as part of a larger 
community of professional learners, and also with their own students. Evidence of focal participants' affective literacies and collegial meaning-making commonly co-occurred in the data, and was found across participants and spanned teachers' multimodal semiotic repertoires of meaning-making. The digitally-networked community of which these cohorts of teachers were a part, given its digital persistence and ways of capturing engagement, afforded methodological tools for tracing the sensorial, embodied, and emergent understandings of literacy which are characteristic of affective literacies. Further, the evidence presented here provide support that digitally-mediated participatory networks allow for the building of social relationships that can enhance teachers' professional learning. The overlaps between affective literacies and collegiality as they appeared in teachers' meaning-making demonstrate the connected nature of social connections and professional learning supported by the existing research literature on collegiality.

\section{Discussion}

In this research project, educators were supported and guided in developing skills and perspectives needed to take greater advantage of affordances of digital tools and texts to increase their learning of ways to also increase and better engage the learning of their students. These new texts and tools offered new forms of literacy and meaning-making, limited only by digital imaginations. This research explicated a number of significant ways that focal participants in the 2017 and 2018 Integrating Technology classes, their students, and other educators in the extended Google+ Community engaged affective literacies and collegial meaning-making activities utilizing the digitally-mediated participatory network constructed by McBride, C. (2018).

In the evidence provided for our findings, we described how the two foci of our research often overlapped in the participants' online activities. Embedded in the exchanges of Marina and Viola, Nett and April, Celina and Kyle, Ashley and other educators, and Darla and her students were clear examples of the importance of emotional content and expression (affect) to the overall process of collegial meaning-making that went well beyond formulaic expressions like "OMG." Jarzabkowski (2002) and other scholars noted in our literature review indicated how general considerations of social sharing among teachers leads to improved cooperation, communication, and emotional commitment. We traced aspects of these kinds of emotive, sharing, and meaning-making activities as they were reflected in digital spaces and found specific ways that the digital spaces themselves contributed to these activities.

For example, exploration was a central aspect of the guided learning, and the Google+ Community enhanced this way of learning by first positioning educators as tinkerers, then allowing easy access by other educators to the tinkering results. Marina tinkered with using the technology to associate memes with literary devices; Nett tinkered with developing a digital quilt to mediate her students' learning; Ashley extended tinkering in Twitter that engaged focal participants with other educators around the country in a synchronous exploration of digitally-mediated discussions. Essentially, the Google+ Community created numerous opportunities for what Ertmer (2005) termed "vicarious exploration" of practitioners both engaging in and modelling technology integration, as in the tutorials described in the findings section.

Additionally, as with the example of Celina and Kyle, the opportunities for emotioned, collaborative meaning-making included ways to link directly to literacy standards, Technological Content Knowledge, and other professional goals of literacy instructors. In the Celina/Kyle example we also saw how the intensity of affect allows for a transvers of issues of self and society (Massumi, 2002; Seigworth \& Gregg, 2010) as Celina leveraged the expanding resources of collegiality to "narrativize" her emotions as they unfolded moment-to-moment (Spinoza, in Seigworth \& Gregg, 2010). These were some of the specific ways that affective dimensions of literacy were revealed in digitally-mediated activities of collegial meaning-making that went beyond strictly cognitive processes and included the emotional and sensorial, as well as ways they are embodied (Mills, Stornaiuolo, Smith, \& Pandya, 2017). 


\section{Conclusion}

In the contemporary educational landscape, it is critical for teachers to develop competencies and confidence in using appropriate digital tools and texts for student learning as well as for their own learning and professional development. Although more work is needed on how digitally-mediated meaning-making is constituted in spaces like Google+ Communities in terms of how they operate as communities of practice in the sense of Lave \& Wenger (1991), we feel this study has helped to clarify a few considerations. It illuminates how the affordances of digital tools and texts expand opportunities to accommodate affective literacies in the processes of collegial meaning-making, and how these tools can facilitate "teachers teaching teachers" in new ways. Educators are able to transcend time, place, and experience; and, new understandings of these dimensions and learning opportunities in and beyond them are needed to apprehend new dynamics of "virtual" and "real," space and place, mind and body, production and consumption, and the rhizomatic connectivity of myriad expressive modalities. OMG, there is much to do.

\section{References}

Baker-Doyle, K. J. (2017). Transformative Teachers: Teacher Leadership and Learning in a Connected World. Cambridge, MA: Harvard Education Press

Berry, B., Daughtrey, A. and A. Wieder, A. (2009). Collaboration: Closing the effective teaching gap [policy brief]. Center for Teaching Quality. Retrieved from: https://www.teachingquality.org/wpcontent/uploads/2018/04/Closing_teacher_effective_gap.pdf

Borthwick, A. C., Pierson, M. E., Anderson, C. L., Morris, J. L., Lathem, S. A., \& Parker, H. B. (2004).

Boyd, D. (2007). Why youth (heart) social network sites: The role of networked publics in teenage social life. In MacArthur Foundation series on digital learning - youth, identity, and digital media.

Brush, T., \& Saye, J. (2009). Strategies for preparing preservice social studies teachers to effectively integrate technology: Models and practices. Contemporary issues in technology and teacher education, $9(1), 46-59$.

Brzycki, D., \& Dudt, K. (2005). Overcoming barriers to technology use in teacher preparation programs. Journal of Technology and Teacher Education, 13(4), 619.

Cochran-Smith, M., \& Lytle, S. L. (2001). Beyond certainty: Taking an inquiry stance on practice. Teachers caught in the action: Professional development that matters, 45-58.

Darling-Hammond, L. (2006). Constructing 21st-century teacher education. Journal of teacher education, 57(3) 300-314.

Davis, K. (2015). Teachers' perceptions of twitter for professional development. Disability \& Rehabilitation, 37(17), 1551-1558.

Dexter, S., Doering, A. H., \& Riedel, E. S. (2006). Content area specific technology integration: A model for educating teachers. Journal of Technology and Teacher Education, 14(2), 325.

Ertmer, P. A. (2005). Teacher pedagogical beliefs: The final frontier in our quest for technology integration? Educational technology research and development, 53(4), 25-39. 
Goddard, Y. L., Goddard, R. D., \& Tschannen-Moran, M. (2007). A theoretical and empirical investigation of teacher collaboration for school improvement and student achievement in public elementary schools. Teachers college record, 109(4), 877-896.

Gomez, L. M., Sherin, M. G., Griesdorn, J., \& Finn, L. E. (2008). Creating social relationships: The role of technology in preservice teacher preparation. Journal of Teacher Education, 59(2), 117-131.

Hickey-Moody \& Haworth (2009). Affective literacies. In D. Masny \& D.R. Cole (Eds.). Multiple literacies theory: A Deleuzian perspective. Sense Publishers.

Hicks, T., Turner, K. H., \& Fink, L. S. (2013). No longer a luxury: Digital literacy can't wait. English Journal, 102(6), 58.

Kelly, N., \& Antonio, A. (2016). Teacher peer support in social network sites. Teaching and Teacher Education, 56,138-149.

Kleiner, B., Thomas, N., \& Lewis, L. (2007). Educational Technology in Teacher Education Programs for Initial Licensure. Statistical Analysis Report. NCES 2008-040. National Center for Education Statistics.

Koehler, M. J., \& Mishra, P. (2009). What is technological pedagogical content knowledge? Contemporary Issues in Technology and Teacher Education, 9(1), 60-70.

Lankshear, C., \& Knobel, M. (2007). Sampling "the new" in new literacies. In M. Knobel \& C. Lankshear (Eds.), A new literacies sampler (pp. 1-24). New York, NY: Peter Lang.

Lave, J., Wenger, E., \& Wenger, E. (1991). Situated learning: Legitimate peripheral participation. Cambridge: Cambridge University Press.

McBride, C. (2018) MUSE Digital Pedagogy Pendent de publicació

Mahiri, J. (2011). Digital tools in urban schools: Mediating a remix of learning. Ann Arbor, MI: University of Michigan Press.

Massumi, B. (2002). Parables for the virtual: Movement, affect, sensation. Durham, NC: Duke University Press.

Mawhinney, L. (2008). Laugh so you don't cry: teachers combating isolation in schools through humour and social support. Ethnography and Education, 3(2), 195-209.

Mawhinney, L. (2010). Let's lunch and learn: Professional knowledge sharing in teachers' lounges and other congregational spaces. Teaching and Teacher Education, 26(4), 972-978.

McDermott, R. (1977). Social relations as contexts for learning in school. Harvard educational review, 47(2), 198-213.

Miles, M. B., Huberman, A. M., \& Saldana, J. (2013). Qualitative data analysis: A methods sourcebook. SAGE Publications, Incorporated.

Mills, K., Stornaiuolo, A., Smith, A., \& Pandya, J., (2017) Handbook of writing, literacies, and education in digital cultures. New York, NY: Routledge. 
Koehler, M. J., \& Mishra, P. (2009). What is technological pedagogical content knowledge? Contemporary Issues in Technology and Teacher Education, 9(1), 60-70.

Morrell, E. (2005). Critical English education. English Education, 37(4), 312-321.

National Council of Teachers of English, (2013). NCTE Definition of 21st Century Literacies. Retrieved January 15, 2017, from http://www2.ncte.org/statement/21stcentdefinition

New London Group. (1996). A pedagogy of multiliteracies: Designing social futures. Harvard Educational Review, 66(1), 60-93.

Papacharissi, Z. (2016). Affective publics and structures of storytelling: Sentiment, events and mediality. Information, Communication \& Society, 19(3), 307-324.

Seigworth, G., \& Gregg, M. (2010). An inventory of shimmers. In M. Gregg \& G. Seigworth (Eds.), The affect theory reader (pp. 138-57). Durham, NC: Duke University Press.

Shulman, L. (1987). Knowledge and teaching: Foundations of the new reform. Harvard Educational Review, 57(1),1-22.

Siemens, G., \& Long, P. (2011). Penetrating the fog: Analytics in learning and education. Educause Review, 46(5), 30. Straub, E. T. (2009). Understanding technology adoption: Theory and future directions for informal learning. Review of educational research, 79(2), 625-649.

Spinoza, B., (1952) Ethics. In Descartes/Spinoza, 349-463. Chicago, IL: Encyclopedia Brittanica.

Stornaiuolo, A., Smith, A., \& Phillips, N. C. (2017). Developing a transliteracies framework for a connected world. Journal of Literacy Research, 49(1), 68-91.

Tobin, D. R. (1998). Building your personal learning network. Retrieved from http://www.tobincls.com/learningnetwork.htm

Trust, T., Krutka, D., \& Carpenter, J. (2016). 'Together we are better': Professional learning networks for teachers. Computers \& Education, 102, 15-34.

Varis, P. (2014). Digital ethnography. Tilburg Papers in Culture Studies, Paper 104. https://www.tilburguniversity.edu/upload/c428e18c-935f-4d12-8afb652e19899a30_TPCS_104_Varis.pdf (Last viewed 5 Nov., 2014). 